Borneo Journal of Sciences \& Technology, 4(1): 06-08

DOI: http://doi.org/10.3570/bjost.2022.4.1-02

e-ISSN: 2672-7439

(C) 2018, UTS Publisher.

Submitted: $10^{\text {th }}$ March 2021

Accepted: $15^{\text {th }}$ July 2021

Published: $31^{\text {st }}$ January 2022

\title{
Proximate Analysis of Ice cream Incorporated with Baccaurea angulata Peel
}

\author{
${ }^{2}$ Isaac Ling Wei An, ${ }^{1,2}$ Suzy Rini Gindi, and ${ }^{2}$ Sebastian Chua Phin Lun \\ ${ }^{1}$ Centre of Research for Innovation and Sustainable Development (CRISD), University of Technology \\ Sarawak, 96000 Sibu, Sarawak, Malaysia \\ ${ }^{2}$ School of Engineering and Technology, University of Technology Sarawak, \\ 96000 Sibu, Sarawak, Malaysia.
}

\begin{abstract}
This study aims to produce ice cream from the outer skin or peel of Baccaurea angulata which also a discarded waste. $B$. angulata is an underutilised tropical wild fruit found in Borneo Island of Malaysia. The skin of B. angulata makes up more than $60 \%$ of the fruit and is loaded with a significant amount of total phenolic content, flavonoid compound and anthocyanin compound. Therefore, this study was the first to study the possibility of incorporating $B$. angulata peel into ice cream to produce healthier and tastier ice cream for the consumers. The method of producing this ice cream is similar to a conventional ice cream production method where the $B$. angulata peel was added into the ice cream mix during the homogenisation process. Proximate analysis and microbiological analysis were conducted to study its nutritional composition as well as its safety. This study indicates the ice cream contains high moisture (43.75\%), and fat (15.90\%), and has an energy value of $292.4 \mathrm{kcal}$ per 100 grams. Moreover, the product is safe for consumption due to the absence of coliform from the total plate count and coliform test.
\end{abstract}

Keywords: Baccaurea angulata, ice cream, Sarawak, physicochemical, proximate analysis.

\section{INTRODUCTION}

Ice cream is a frozen dairy product made by freezing the ice cream mix with agitation. Goff and Hartel (2013) stated that an ice cream consists of milk fat, milk solids-not-fat (MSNF), sweetening ingredients, water, stabilisers, emulsifiers, egg products, flavouring and colouring [1]. The ingredients will give an organoleptic property like taste, appearance and texture to the ice cream.

The increased health awareness among consumers has motivated the development of ice creams that offer health benefits such as ice cream with natural antioxidants or low-fat ice cream. In line with consumer expectation for healthier and delightful ice creams, new formulation of ice cream containing natural fruits or fruit extracts are being produced and introduced to the market. This has opened up to numerous possibilities for new kind of ice cream [2];[3]. Thus, this study takes these possibilities as an opportunity to use $B$. angulata fruit peel into the ice cream.

Borneo Island of Malaysia is well known for its rich biodiversity. B. angulata, also known locally as "Buah Uchong", "Belimbing Hutan" or "Belimbing Merah", is an underutilised tropical wild fruit. It comes with various colours ranging from pink to purple. The flesh of the fruit is eaten by the natives as part of their diets but the skin that makes up to $69.28 \%$ of its weight has been discarded [4].

Several studies [4];[5];[6] have documented that the skin of $B$. angulata contains a significant amount of total phenolic content, flavonoid compound and anthocyanin compound compared to its flesh. These results indicated that the skin of $B$. angulata could be incorporated into ice cream to create a healthier ice cream for consumers. Therefore, this research aims to develop an ice cream from the outer skin waste material of $B$. angulata and also determine its nutritional value.

\section{MATERIALS AND METHODS}

\section{Sample Collection and Preparation}

B. angulata fruits were obtained from the divisions of Sibu, Sarikei, Mukah and Kapit in the central of Sarawak, Malaysia. The ripe fruit with pinkies colour was bought. Throughout the study, the Baccaurea angulata was bought in bulks and kept in frozen stage at $-20^{\circ} \mathrm{C}$ to preserve the quality before use. 


\section{Proximate Analysis of Ice cream Incorporated with Baccaurea angulata Peel}

The preparation of $B$. angulata fruits include sorting between good and bad fruits, washed to removed dirt and contaminants, cut to separate pulp and peel, and lastly blended to puree the fruit peels. The blended puree and fruit peel dice also will be kept in frozen condition.

\section{Ice cream Production}

The ingredients used in ice cream productions includes milk, heavy cream, sugar and $B$. angulata peel puree. The variables in production of this most accepted ice cream are heavy cream and B. angulata peel puree. The first step to produce $B$. angulata ice cream is by heating the milk to $50^{\circ} \mathrm{C}$ before adding in heavy cream. The mixture continuously heated to $60^{\circ} \mathrm{C}$. Then sugar was added and mixture was pasteurized at $85^{\circ} \mathrm{C}$ for 5 minutes, before it cooled to $50^{\circ} \mathrm{C}$. This ice cream mix will then again mix with $B$. angulata's peel puree. Then the ice cream mixture will be going through homogenization process for 5 minutes and done. Before ice cream mixture can be made to ice cream, it was aged for 24 hours in chill conditions $\left(4^{\circ} \mathrm{C}\right)$. The next day, ice cream mixture was poured into the ice cream maker until it finally become soft ice cream.

\section{Proximate Analysis}

Proximate analysis was conducted on the most wellaccepted ice cream formulation (by sensory evaluation). Proximate analysis for moisture content, ash, protein and fat was based on AOAC methods. The moisture content was determined by drying 2 grams of sample in a vacuum oven at $60^{\circ} \mathrm{C}, 67 \mathrm{mb}$ for 2 hours until a constant weight was obtained [7]. The ash content was determined by using dry ashing method where 5 grams of sample was incinerated in a Nabertherm furnace at $600^{\circ} \mathrm{C}$ for 2 hours. The crude protein content was determined by using Kjeldahl method [7]. 2 grams of sample was digested, distillated and titrated to determine the nitrogen content. The percentage of protein was calculated with the conversion factor of 6.38 . The crude fat content was determined by using Modified Mojonnier Ether Extraction method where fat is extracted with mixture of ethers from 5 grams of ice cream sample. Meanwhile, calculation for carbohydrate, energy and overrun were done based on James analytical method. Carbohydrate was calculated by subtracting the sum of protein, fat, moisture, ash and crude fibre from 100\% [8]. The energy content was calculated by adding the calories from protein, carbohydrate and fat [8]. The overrun was measure of how much it was reduced and expressed in percent (\%) [8]. All analyses were performed in triplicates.

\section{Microbiological Analysis}

Total plate count and coliform count were conducted as indicator for microbiological analysis of ice cream sample [9]. All analyses were conducted in triplicates.

\section{RESULTS AND DISCUSSION}

\section{Proximate Analysis}

Moisture content of ice cream was analysed to be $43.75 \%$ which is less than the value found in the literature in comparison to that of vanilla ice cream which is $61.70 \%$ [10]. The result was expected as ice cream with high fat content tend to have less moisture content [11]. Fat content of ice cream was analysed to be $15.90 \%$ which is in accordance to Malaysia Food Regulation 1985 where ice cream shall contain not less than $10 \%$ of milk fat. High amount of fat content was due to the addition of heavy cream [10];[12]. Ice cream with high fat content is favourable as it enhances the mouthfeel by increasing the viscosity and melting resistance in ice cream [11];[13];[14]. Total carbohydrate content of ice cream was calculated to be $38.64 \%$. Ice cream with high carbohydrate content is favorable as it influences the texture of ice cream by increasing the viscosity as well as softness of ice cream [11];[13];[14]. The energy value per 100 gram of ice cream was calculated to be $292.4 \mathrm{kcal}$ which falls in the commercial ice cream energy range of $170 \mathrm{kcal}$ to $300 \mathrm{kcal}$ depending on the constituents that affect the overall energy. This can be explained by the high fat content in ice cream where 1 gram of fat provides 9 kilocalories. The overrun of ice cream was calculated to be $76.66 \%$ which was accepted [2]. High overrun was resulted from the high amount of fat content where there are more coalesced fat droplets to trap the air bubbles. Hence, small ice crystal will give a smooth, lighter and fluffy texture that regulate the sensory properties of ice cream [11];[13];[14].

Table 1. Proximate composition and overrun percentage of Baccaurea angulata peel ice cream

\begin{tabular}{l|c}
\hline Nutrition Composition & $\begin{array}{r}\text { Baccaurea angulata peel } \\
\text { ice cream }\end{array}$ \\
\hline Moisture (\%) & 43.75 \\
Ash (\%) & 1.00 \\
Protein (\%) & 0.71 \\
Fat (\%) & 15.90 \\
Carbohydrate (\%) & 38.64 \\
Energy value (kcal) & 292.40 \\
Overrun (\%) & 76.66 \\
\hline
\end{tabular}




\section{Microbiological Analysis}

The microbiological analysis of ice cream indicated that the ice cream is safe to consume as it gave negative results for total plate count and coliform test [9]. This was due to the effective pasteurisation of ice cream mix and the hygiene manner during ice cream making process.

Table 2. Microbiological analysis of Baccaurea angulata peel ice cream

\begin{tabular}{l|l}
\hline Parameters & Result \\
\hline $\begin{array}{l}\text { Total plate count } \\
\text { Coliform test }\end{array}$ & $\begin{array}{l}\text { Negative } \\
\text { Negative }\end{array}$ \\
\hline
\end{tabular}

\section{CONCLUSION}

This research demonstrated the potential of incorporating ice cream with the $B$. angulata fruit peel which consider as waste material. The moisture content $(43.75 \%)$ is low compare with regular ice cream because of high fat content $(15.90 \%)$. The high content of fat and carbohydrate $(38.64 \%)$ also contribute to high energy value which is $292.40 \mathrm{kcal}$. Meanwhile, high overrun $(76.66 \%)$ will improve texture and regulate sensory properties. The negative results of microbiological analysis on the ice cream indicated it is safe to consume.

\section{ACKNOWLEDGMENT}

We thank the Centre for research and development department of University of Technology for grant us a funding to finance this research and also School of Engineering and Technology for its facilities.

\section{REFERENCES}

[1] Goff, H.D. and Hartel, R.W., 2013. Ice Cream. 7 th ed. Springer, New York: New York.

[2] Sun-Waterhouse, D., Edmonds, L., Wadhwa, S.S. and Wibisono, R., 2013. Producing ice cream using substantial amount of juice from kiwifruit with green, gold or red flesh. Food Research International, 50(2013), 647-656.

[3] Karaman, S., Toker, O.S., Yuksel, F., Cam, M., Kayacier, A. and Dogan, M., 2014.
Physicochemical, bioactive, and sensory properties of persimmon-based ice cream: Technique for order preference by similarity to ideal solution to determine optimum concentration. Journal of Dairy Science, 97(1), 97-109.

[4] Ahmed, I.A., Mikail, M.A., Ibrahim, M., Hazali, N., Rasad, M.S.B.A., Ghani, R.A., Wahab, R.A., Arief, S.J. and Yahya, M.N.A., 2015. Antioxidant activity and phenolic profile of various morphological parts of underutilized Baccaurea angulata fruit. Food Chemistry, 172(2015), 778-787.

[5] Darina, I., Norazlanshah, H., Nurhaznikhir, J. and Muhammad, M.N., 2013. Physicochemical and antioxidant characteristics of Baccaurea angulata fruit juice extract. African Journal of Biotechnology, 12(34), 5333-5338.

[6] Norazlanshah, H., Affiq, M.A.M., Ibrahim, M. and Masri, M., 2015. Determination of phytochemicals and vitamin content of underutilized Baccaurea angulata fruit. Journal of Pharmacognosy and Phytochemistry, 4(4), 192-196.

[7] AOAC, 2016. Official Methods of Analysis of AOAC International, 20th Edition. Gaithersburg, Maryland, U.S.A: AOAC International.

[8] James, C.S., 2013. Analytical chemistry of foods. Springer Science \& Business Media.

[9] Legal Research Board. 2017. Food Act 1983 (Act 281) \& Regulations. Kuala Lumpur: International Law Books Services

[10] Arbuckle, W.S., 1986. Ice Cream, 4th edition. West Port, Connecticut: Avi Publishing Co. Inc.

[11] Pinheiro, M.V.S. and Penna, A.L.B., 2004. Substitutos de gordura, tipos e aplicações em produtos lácteos. Alimentos e Nutrição, 15(2), 175-186.

[12] Zheng, L., Marshall, R., Heymann, H., and Ernando, L., 1997. Effect of milk fat content on flavour perception of vanilla ice cream. Journal of Dairy Science, 80, 3133-3141.

[13] Souza, J.C.B., Costa, M.R., de Rensis, C.M.V.B. and Sivieri, K., 2010. Sorvete, composição, processamento e viabilidade da adição de probiótico. Alimentos e Nutrição, 21(1), 155-165

[14] Mosquim, M.C.A., 1999. Fabricando sorvete com qualidade. São Paulo: Varela. 62 